\title{
Effects of inhaled nitric oxide on methacholine-induced bronchoconstriction: a concentration response study in rabbits
}

\author{
M. Högman*, S-Z. Wei*, C. Frostell**, H. Arnberg*, G. Hedenstierna*
}

Effects of inhaled nitric oxide on methacholine-induced bronchoconstriction: a concentration response study in rabbits. M. Högman, S-Z. Wei, C. Frostell, H. Arnberg, G. Hedenstierna. CERS Journals Ltd 1994.

ABSTRACT: Inhaled nitric oxide (NO), at a concentration of $80 \mathrm{ppm}$, counters the increase in respiratory resistance (Rrs) induced by methacholine, but fails to prevent a reduction in lung compliance $(\mathrm{Crs})$ in a rabbit model. This study reports the effects of 3, 30 and $300 \mathrm{ppm}$ of inhaled NO.

New Zealand White rabbits were intubated and mechanically ventilated with $30 \%$ oxygen during neurolept anaesthesia. Methacholine $\left(3 \mathrm{mg} \cdot \mathrm{ml}^{-1}\right)$ was nebulized, with or without NO inhalation.

Inhalation of 3 and $30 \mathrm{ppm}$ NO had no effect on the induced bronchoconstriction, whereas $300 \mathrm{ppm}$ fully blocked the increase in Rrs. The decrease in Crs due to methacholine was not countered by 3,30 or $300 \mathrm{ppm}$ NO. On the contrary, inhalation of $300 \mathrm{ppm} \mathrm{NO}$ in itself decreased Crs from $5.0 \pm 0.1$ to $4.3 \pm 0.1 \mathrm{ml} \cdot \mathrm{cmH}_{2} \mathrm{O}^{-1}$. Also, mean arterial pressure $(60 \pm 7$ to $54 \pm 5 \mathrm{mmHg})$, alveolar-arterial oxygen tension gradient $(0.8 \pm 0.8$ to $2.3 \pm 1.8 \mathrm{kPa})$ and methaemoglobin $(0.5 \pm 0.2$ to $1.5 \pm 0.5 \%)$ changed significantly on inhalation of NO $300 \mathrm{ppm}$ prior to methacholine challenge.

We conclude that 3 and $30 \mathrm{ppm}$ NO inhalation does not alter methacholineinduced bronchoconstriction. Inhalation of $300 \mathrm{ppm}$ NO blocks an increase in resistance but fails to counter the reduction in compliance due to methacholine. This suggests that the bronchodilating effects of $\mathrm{NO}$ in rabbits in vitro are confined to the large airways.

Eur Respir J., 1994, 7, 698-702.
*Dept of Clinical Physiology, University Hospital, Uppsala, Sweden. **Dept of Anesthesia and Intensive Care, Danderyd Hospital, Danderyd, Sweden.

Correspondence: G. Hedenstierna Dept of Clinical Physiology

University Hospital

S-751 85 Uppsala

Sweden

Keywords: Airway resistance

lung compliance

methacholine chloride nitric oxide

rabbits

Received: July 301993

Accepted after revision December 131993

This study was supported by grants from AGA Medical Research Fond, Swedish Heart and Lung Foundation, the Swedish Medical Research Council (5315) and Marquette Electronics Inc., USA.
The administration of inhaled nitric oxide (NO) as a selective pulmonary vasodilator $[1,2]$ is currently being investigated in several forms of severe respiratory failure [3-5]. It has also been shown that inhaled NO can act as a bronchodilator in guinea-pigs [6], and rabbits [7]. Inhaled NO, $80 \mathrm{ppm}$, has a bronchodilatory effect on patients with bronchial asthma, but compared to an inhaled $\beta_{2}$-agonist the effect is modest [8]. Dupuy et al. [6] showed that low concentrations $(5 \mathrm{ppm})$ of $\mathrm{NO}$ could reduce respiratory resistance and that high concentrations (100 ppm) improved compliance, when an intravenous infusion of methacholine ( $\mathrm{MCh}$ ) was given to guineapigs. Inhalation of $80 \mathrm{ppm}$ NO prevented the increase in respiratory resistance (Rrs) induced by methacholine nebulization in a rabbit model, but failed to improve lung compliance (Crs) [7]. These differences in response to MCh may be explained by a difference in species used and administration of $\mathrm{MCh}$, and prompted this concentration-response study in the rabbit.

We investigated the effects of a low NO concentration (3 ppm), a concentration similar to that presently advocated for the treatment of pulmonary hypertension (30 ppm), and a high NO concentration (300 ppm), in our rabbit model, in which bronchoconstriction was induced by MCh nebulization.

Materials and methods

\section{Animal preparation}

We studied 18 New Zealand White rabbits of both sexes, with a body weight of $3.2-3.6 \mathrm{~kg}$. They were vaccinated against Pasteurella and Bordetella and maintained on ad libitum water and $75 \mathrm{~g}$ of high protein pellets a day. Premedication of $0.5 \mathrm{ml}$ Hypnorm (Janssen, Belgium) [9] was given i.m. The marginal ear vein was used for $i . v$. injections, whilst the ear artery was used for blood sampling and pressure monitoring. Before intubation, $1 \mathrm{ml}$ Hypnorm i.m. and $5 \mathrm{mg}$ diazepam i.v. were given. Intubation was performed with a cuffed tube 3.0 (Sheridan, USA). The rabbit was placed in the prone position on a heating pad to maintain normal body temperature. Artificial ventilation was given with a Siemens 900C ventilator (Siemens-Elema, Sweden), with an inspired 
oxygen fraction $\left(\mathrm{FIO}_{2}\right)$ of 0.3 , an inspiratory to expiratory ratio of 1:2, tidal volume (VT) $38 \mathrm{ml}$ and a ventilatory frequency of about 30 breaths $\cdot \mathrm{min}^{-1}$. The ventilatory frequency was adjusted to keep the end-tidal carbon dioxide tension $\left(\mathrm{PETCO}_{2}\right)$ (Eliza duo, Gambro-Engström $\mathrm{AB}$, Sweden) around $5 \mathrm{kPa}$, verified with blood gas analysis for determination of arterial $\mathrm{CO}_{2}$ and $\mathrm{O}_{2}$ tensions $\left(\mathrm{PaCO}_{2}\right.$ and $\left.\mathrm{PaO}_{2}\right)(\mathrm{ABL}, 300$, Radiometer, Denmark). The alveolar-arterial oxygen tension gradient $\left(\mathrm{PA}_{-}-\mathrm{OO}_{2}\right)$ was calculated, using the alveolar oxygen tension derived from the alveolar gas equation [10].

Mean arterial pressure (MAP) was continuously monitored (Tram 7010, Marquette Electronics Inc., WI, USA). The anaesthesia was maintained with i.v infusion of Hypnorm $0.1-0.3 \mathrm{mg} \cdot \mathrm{kg}^{-1} \cdot \mathrm{h}$ and $2.5 \mathrm{mg}$ diazepam i.v. as necessary. A muscle relaxant, $0.2 \mathrm{mg}$ pancuronium bromide, was given i.v. At the end of the experiment, the muscle paralysis was antagonized with $0.15 \mathrm{mg}$ neostigmine and $0.03 \mathrm{mg}$ glycopyrronium. In addition, naloxone was given i.v. as needed to counteract hypoventilation due to residual Hypnorm effects.

\section{Experimental procedure}

The animals were divided into three groups of six rabbits each. The three groups inhaled 3, 30 or $300 \mathrm{ppm}$ NO, respectively. The rabbits served as their own controls [11] and were, therefore, anaesthetized twice. Two weeks were allowed between the first and the second $\mathrm{MCh}$ provocation, with and without NO inhalation, in a randomized fashion. After a $30 \mathrm{~min}$ stabilization period, a double $\mathrm{V}_{\mathrm{T}}$ was delivered to reopen any collapsed lung tissue. An inflation pressure (Pmax) limit was set at 25 $\mathrm{cmH}_{2} \mathrm{O}$.

NO was inhaled for $10 \mathrm{~min}$ prior to, as well as during, the nebulization of MCh with a concentration of 3 $\mathrm{mg} \cdot \mathrm{ml}^{-1}$. Methacholine chloride was dissolved in distilled water with $\mathrm{pH}$ corrected to $7.01 \pm 0.12$ (mean $\pm 95 \%$ confidence interval). Respiratory mechanics were measured and blood gases were obtained at baseline, at NO inhalation and within 2 min after MCh challenge. Respiratory mechanics were also measured $30 \mathrm{~min}$ after MCh challenge.

\section{Determination of respiratory mechanics}

Measurements of Crs and Rrs were obtained using the technique of rapid airway occlusion during constant-flow inflation $[12,13]$. Rrs is the difference between Pmax and the pressure $2 \mathrm{~s}$ after the end-inspiratory pause, divided by the flow [14], with the endotracheal tube resistance of $28 \mathrm{cmH}_{2} \mathrm{O} \cdot l^{-1} \cdot \mathrm{s}$ subtracted. Crs was calculated as $\mathrm{V}_{\mathrm{T}}$ divided by the end-inspiratory pressure minus the end-expiratory pressure. Pressure and flow were measured in the ventilator on the inspiratory side, and fed into a computer for on-line signal processing (MacII Fx computer with LabView 2 software, USA). For gas compression in the tubing, corrections were made for volume and flow values. A mean value of two "inspiratory hold" manoeuvres was used for each point. The sampling of data was performed within $30 \mathrm{~s}$ of completion of the MCh challenge.

\section{Statistical analysis}

Statistical analysis was performed using Student's twotailed test for paired data. The responses to MCh, with or without NO inhalation, were tested with analysis of variance (ANOVA) (SigmaStat, Jandel Scientific, Erkrath, Germany). Results are given as mean values $\pm 95 \%$ confidence interval in the text and \pm standard error of mean (SEM) in the figures. A value of $\mathrm{p}<0.05$ was considered statistically significant.

\section{Results}

Body weight and temperature, as well as pre-inhalation values of MAP, $\mathrm{PaO}_{2}, \mathrm{PETCO}_{2}$, Pmax, Rrs and Crs showed no change between the first and the second anaesthesia two weeks later (data not shown).

\section{Effect of NO inhalation}

Inhalation of NO 3 and $30 \mathrm{ppm}$ did not significantly alter baseline data, whilst NO at a concentration of 300 ppm significantly altered MAP, $\mathrm{PA}_{\mathrm{A}} \mathrm{aO}_{2}, \mathrm{Crs}$ and methaemoglobin (metHb) (table 1).

Table 1. - Effect of NO inhalation, 300 ppm

\begin{tabular}{|c|c|c|}
\hline & Control & NO 300 ppm \\
\hline $\mathrm{Pmax} \mathrm{cmH}_{2} \mathrm{O}$ & $12.0 \pm 0.8$ & $12.5 \pm 0.8$ \\
\hline MAP mmHg & $60 \pm 7$ & $54 \pm 5 *$ \\
\hline HR bpm & $234 \pm 11$ & $235 \pm 10$ \\
\hline $\mathrm{PA}-\mathrm{aO}_{2} \quad \mathrm{kPa}$ & $0.8 \pm 0.8$ & $2.3 \pm 1.8 *$ \\
\hline $\mathrm{PETCO}_{2} \quad \mathrm{kPa}$ & $5.4 \pm 0.2$ & $5.4 \pm 0.3$ \\
\hline $\mathrm{Rrs} \quad \mathrm{cmH}_{2} \mathrm{O} \cdot l^{-1} \cdot \mathrm{s}$ & $56 \pm 4$ & $56 \pm 13$ \\
\hline $\mathrm{Crs} \mathrm{ml} \cdot \mathrm{cmH}_{2} \mathrm{O}^{-1}$ & $5.0 \pm 0.1$ & $4.3 \pm 0.1 *$ \\
\hline metHb \% & $0.5 \pm 0.2$ & $1.5 \pm 0.5^{*}$ \\
\hline
\end{tabular}

Data are presented as mean value $\pm 95 \%$ confidence interval. Pmax: maximum insufflation pressure; MAP: mean arterial pressure; $\mathrm{HR}$ : heart rate; $\mathrm{PA}_{\mathrm{A}} \mathrm{aO}_{2}$ : alveolar-arterial oxygen tension gradient; $\mathrm{PETCO}_{2}$ : end-tidal carbon dioxide tension; Rrs: respiratory resistance; Crs: lung compliance; metHb: methaemoglobin. *: $\mathrm{p}<0.05$.

\section{Effect of NO inhalation on methacholine-induced} bronchoconstriction

Inhalation of 3 ppm NO. MCh nebulization resulted in a rapid increase in Rrs in the control situation, from a baseline of $47 \pm 8$ to $77 \pm 20 \mathrm{cmH}_{2} \mathrm{O} \cdot l^{-1} \cdot \mathrm{s}(\mathrm{p}<0.01)$. The Rrs tended to increase from $55 \pm 8$ to $86 \pm 41 \mathrm{cmH}_{2} \mathrm{O} \cdot l^{-1} \cdot \mathrm{s}$ (NS) during NO inhalation when $\mathrm{MCh}$ was nebulized (fig. 1). Crs fell due to MCh nebulization in the control situation, from a baseline of $4.6 \pm 0.5$ to $3.4 \pm 0.9 \mathrm{ml} \cdot \mathrm{cmH}_{2} \mathrm{O}^{-1}$ $(p<0.01)$. With NO inhalation, Crs decreased from $4.3 \pm 0.3$ 

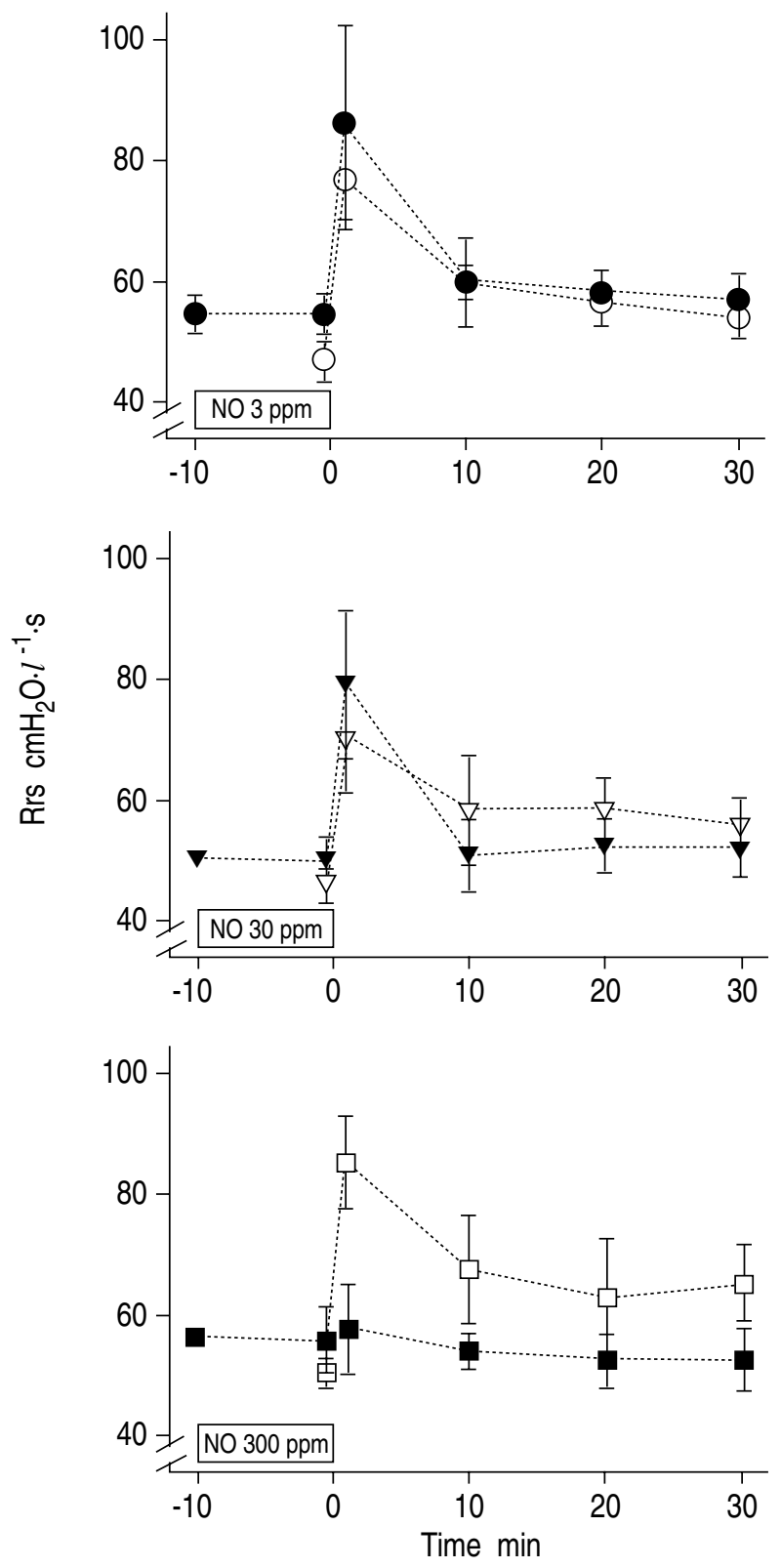

Fig. 1. - Change in respiratory resistance (Rrs) to methacholine (MCh) with or without nitric oxide (NO) inhalation. Rrs is shown prior to MCh nebulization, within one minute after the nebulization and during a follow-up period of $30 \mathrm{~min}$. Hollow symbols: control (without NO); filled symbols: NO was inhaled $10 \mathrm{~min}$ before as well as during MCh nebulization. Inhalation of $3 \mathrm{ppm}(\mathbf{)})$ and $30 \mathrm{ppm} \mathrm{NO}$ ( $\nabla)$ did not block the increase in Rrs due to MCh. An absence of response to $\mathrm{MCh}$ was seen when $300 \mathrm{ppm} \mathrm{NO}$ (ם) was inhaled. $\mathrm{p}<0.01$, analysis of variance (ANOVA).

to $3.2 \pm 0.9 \mathrm{ml} \cdot \mathrm{cmH}_{2} \mathrm{O}^{-1}(\mathrm{p}<0.05)$ (fig. 2). The $\mathrm{PA}_{-}-\mathrm{aO}_{2}$ increased from $1.5 \pm 0.4$ to $4.9 \pm 2.6 \mathrm{kPa}(\mathrm{p}<0.05)$ in the control situation when MCh was nebulized. During NO inhalation the $\mathrm{PA}_{\mathrm{A}-\mathrm{aO}}$ changed from $1.7 \pm 1.7$ to $6.1 \pm 5.9$ $\mathrm{kPa}$ (NS). In conclusion, there was no significant difference in response to $\mathrm{MCh}$, whether NO had been inhaled or not.

Inhalation of $30 \mathrm{ppm} N O$. In the control situation, when MCh was nebulized Rrs increased from $46 \pm 8$ to $70 \pm 21$ $\mathrm{cmH}_{2} \mathrm{O} \cdot l^{-1} \cdot \mathrm{s}(\mathrm{p}<0.05)$. With NO inhalation, Rrs increased
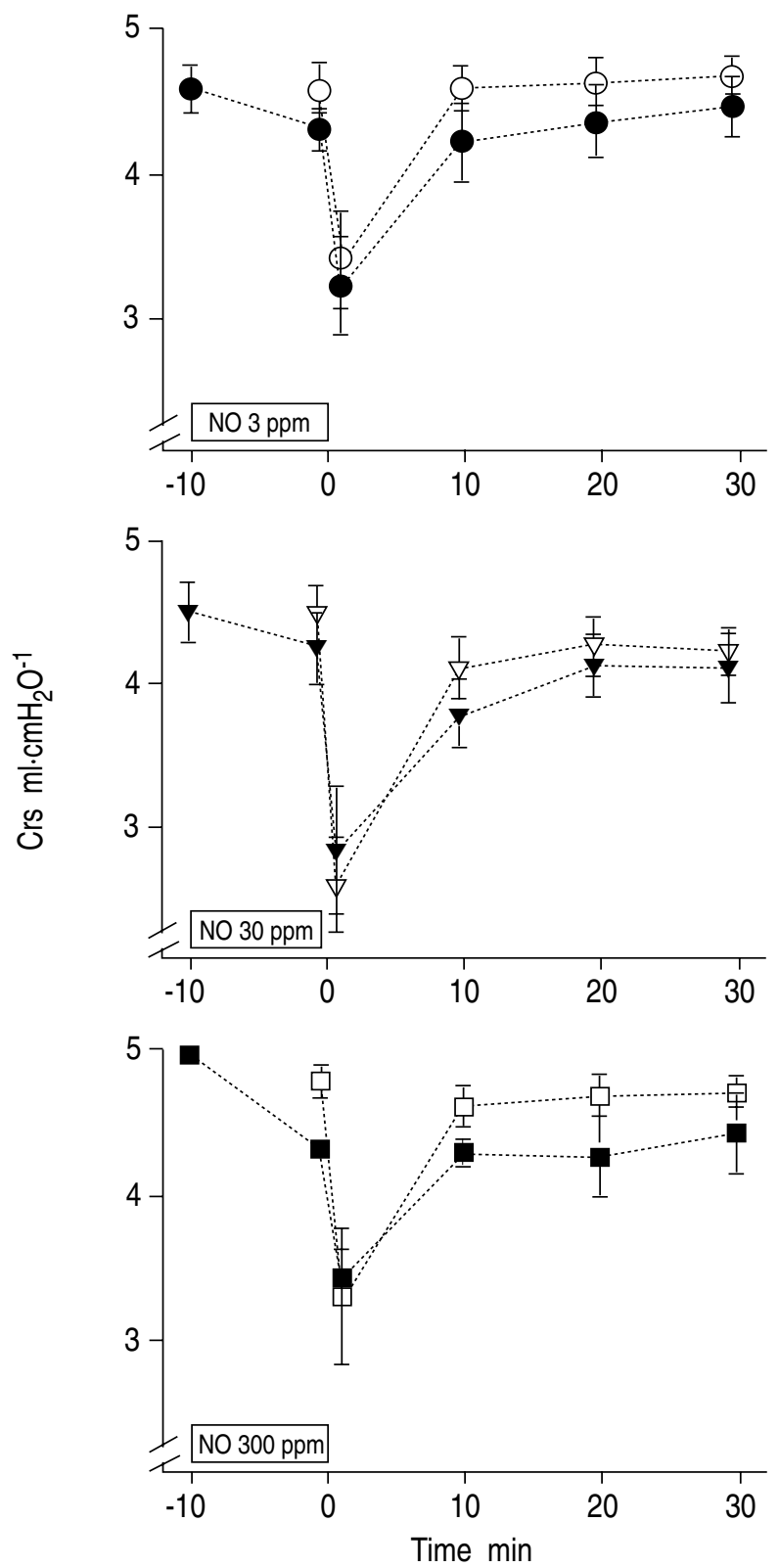

Fig. 2. - Change in lung compliance (Crs) to methacholine (MCh) with and without nitric oxide (NO). Crs is shown prior to $\mathrm{MCh}$ nebulization, within one minute after the nebulization and during a follow-up period of $30 \mathrm{~min}$. Hollow symbols: control (without NO); filled symbols: NO was inhaled $10 \mathrm{~min}$ before as well as during $\mathrm{MCh}$ nebulization. Inhalation of $3 \mathrm{ppm}(\boldsymbol{\bullet})$ and $30 \mathrm{ppm} \mathrm{NO}(\boldsymbol{\nabla})$ did not block the decrease in Crs due to MCh. Inhalations of $300 \mathrm{ppm}$ (NO) ( $)$ decreased Crs ( $\mathrm{p}<0.05$, analysis of variance (ANOVA) but the response to $\mathrm{MCh}$ was not altered from the control situations.

from $50 \pm 8$ to $79 \pm 31 \mathrm{cmH}_{2} \mathrm{O} \cdot l^{-1} \cdot \mathrm{s}(\mathrm{p}<0.05)$ (fig. 1). Crs decreased due to $\mathrm{MCh}$ in the control situation to $2.6 \pm 0.8$ $\mathrm{ml} \cdot \mathrm{cmH}_{2} \mathrm{O}^{-1}$, from a baseline value of $4.5 \pm 0.5 \mathrm{ml} \cdot \mathrm{cmH}_{2} \mathrm{O}^{-1}$ $(\mathrm{p}<0.001)$. With NO inhalation, Crs decreased from $4.2 \pm$ 0.6 to $2.8 \pm 1.1 \mathrm{ml} \cdot \mathrm{cmH}_{2} \mathrm{O}^{-1}(\mathrm{p}<0.05)$ (fig. 2). $\mathrm{PA}_{-} \mathrm{aO}_{2}$ increased from $0.9 \pm 0.5$ to $5.7 \pm 3.9 \mathrm{kPa}(\mathrm{p}<0.05)$ in the control situation when MCh was nebulized. During NO inhalation, $\mathrm{PA}_{-} \mathrm{aO}_{2}$ changed from $1.1 \pm 0.4$ to $6.4 \pm 4.5$ $\mathrm{kPa}(\mathrm{p}<0.05)$. There was, thus, no significant difference in response to $\mathrm{MCh}$, whether NO had been inhaled or not. 
Inhalation of $300 \mathrm{ppm}$ NO. The Rrs increased from $50 \pm 5$ to $85 \pm 20 \mathrm{cmH}_{2} \mathrm{O} \cdot l^{-1} \cdot \mathrm{s}(\mathrm{p}<0.01)$ in the control situation. With NO inhalation, the Rrs did not change. The baseline value was $45 \pm 13 \mathrm{cmH}_{2} \mathrm{O} \cdot l^{-1} \cdot \mathrm{s}$, and with $\mathrm{NO}$ inhalation during MCh nebulization $46 \pm 18 \mathrm{cmH}_{2} \mathrm{O} \cdot l^{-1} \cdot \mathrm{s}$, significantly different compared to the response to $\mathrm{MCh}$ without NO ( $<<0.01$, ANOVA) (fig. 1). In the control situation, Crs decreased from $4.8 \pm 0.3$ to $3.3 \pm 1.2 \mathrm{ml} \cdot \mathrm{cmH}_{2} \mathrm{O}^{-1}$ $(\mathrm{p}<0.05)$, and with NO inhalation the Crs decreased from $4.3 \pm 0.1$ to $3.4 \pm 0.4 \mathrm{ml} \cdot \mathrm{cmH}_{2} \mathrm{O}^{-1}(\mathrm{p}<0.01)$ (fig. 2). $\mathrm{PA}_{-}-\mathrm{aO}_{2}$ in the control situation was $1.3 \pm 0.7$ and increased with $\mathrm{MCh}$ nebulization to $6.2 \pm 4.2 \mathrm{kPa}(\mathrm{p}<0.05)$. When NO was added, the $\mathrm{PA}_{-} \mathrm{aO}_{2}$ increased from $2.25 \pm 1.8$ to $4.6 \pm 2.9$ $\mathrm{kPa}(\mathrm{p}<0.01)$ due to $\mathrm{MCh}$ nebulization.

\section{Discussion}

This study in rabbits shows that low nitric oxide concentrations, i.e. 3 and $30 \mathrm{ppm}$, do not alter the increase in resistance or the reduction in compliance when bronchoconstriction is induced by methacholine nebulization. This study also shows that a high NO concentration, i.e. $300 \mathrm{ppm}$, completely blocks the increase in resistance, but fails to counter the reduction in compliance due to MCh nebulization. Interestingly, we found that $300 \mathrm{ppm}$ NO inhalation in itself decreases Crs and mean arterial blood pressure, and increases $\mathrm{PA}_{\mathrm{A}} \mathrm{aO}_{2}$ and methaemoglobin concentration.

We found previously that $80 \mathrm{ppm}$ NO blocked the increase in resistance to a subsequent $\mathrm{MCh}$ nebulization [7]. Our findings in the previous as well as the present study are at variance with those of Dupuy et al. [6], who found that even at 5 ppm NO significantly reduced the increase in resistance caused by intravenous $\mathrm{MCh}$ in the guinea-pig. Moreover, Dupuy et al. [6] showed a significant improvement in compliance with 100 and 300 ppm NO during MCh infusion, whereas we saw no protective effect on compliance with 300 ppm NO during MCh nebulization. These differences may be due to open versus closed chest preparations, the difference in species studied and/or systemic versus local administration of MCh. We interpret the different effects of $\mathrm{NO}$ on Rrs and Crs to dilation of mainly large airways, with less or only minor effects on small airways. It is worthy of note that isolated canine tracheal muscle strips tended to relax more than bronchial strips when NO was added to the tissue bath [15].

It also seems that higher inspired concentrations of NO are required to dilate airways in our rabbit model [7] (and present study) and in subjects with hyperreactive airways and asthmatics $[16,8]$, than are required to dilate pulmonary vessels [1-3]. This may be due to lower sensitivity to NO in the bronchial wall, or to a poor penetration from the airway lumen to the bronchial smooth muscle. A difference in the sensitivity to NO has been demonstrated in in vitro experiments [15]. Canine airway smooth muscle was 10 times less sensitive compared to vascular smooth muscle. It has also been shown that inhaled NO dilates bronchial vessels and increases bronchial blood flow [17], an effect that has been shown for
MCh also [18]. A hyperaemic airway mucosa may interfere with the diffusion of inhaled NO to the airway smooth muscle, and there may be inactivation of NO by the haemoglobin. The pathogenesis of asthma has been shown to be closely linked to the presence of airway inflammation [19] with a hyperaemic and swollen airway lining.

In asthmatic patients, $80 \mathrm{ppm} \mathrm{NO}$ inhalation did not have a consistent bronchodilator effect [8], perhaps due to low receptor sensitivity or poor penetration. This has led to advocation for giving higher NO concentrations. However, a number of negative effects must then be considered, including $\mathrm{NO}_{2}$ formation, and the decrease in $\mathrm{Crs}$ and increase in $\mathrm{PA}_{-}-\mathrm{aO}_{2}$ found in our present study.

Increased NO concentrations will facilitate the formation of $\mathrm{NO}_{2}$, a bronchial irritant. $\mathrm{NO}_{2}$ concentrations as low as $0.5 \mathrm{ppm}$ increase airway responsiveness [20] and higher concentrations may cause pulmonary oedema [21, 22]. Thus, inhaled $\mathrm{NO}_{2}$ levels must be kept very low and be closely monitored. The decrease in Crs may possibly be related to vascular dilation and airway oedema, with subsequent small airway narrowing and closure. The unexpected increase in $\mathrm{PA}_{\mathrm{A}} \mathrm{aO}_{2}$ may be due to diffusion of NO into the lung tissue and blood, reaching the dilating pulmonary vessels in poorly ventilated areas. More research is clearly needed before inhaled NO of higher concentrations can be advocated in the treatment of asthma.

In summary, high NO concentrations, i.e. $\geq 80 \mathrm{ppm}$, are needed to produce any effect on the increase in resistance when bronchoconstriction is induced by methacholine nebulization. However, lung compliance still remains low. This indicates that the bronchodilatory effects of NO are mainly confined to large airways, with less or only minor effects on small airways. The observation that $300 \mathrm{ppm}$ NO in itself changes lung compliance, alveolar-arterial oxygen tension gradient and mean arterial pressure needs further investigation.

\footnotetext{
Acknowledgements: The authors gratefully acknowledge M. Hall for skillful technical assistance.
}

\section{References}

1. Frostell CG, Fratacci M-D, Wain JC, Zapol WM. Inhaled nitric oxide: a selective pulmonary vasodilator reversing hypoxic pulmonary vasoconstriction. Circulation 1991; 83: 2038-2047.

2. Pepke-Zaba J, Higenbottam TW, Dinh-Xuan AT, Stone $\mathrm{D}$, Wallwork J. Inhaled nitric oxide as a cause of selective pulmonary vasodilation in pulmonary hypertension. Lancet 1991; 33: 1173-1174.

3. Rossaint R, Falke KJ, Lopez F, Slama K, Pison U, Zapol WM. Inhaled nitric oxide in adult respiratory distress syndrome. N Engl J Med 1993; 328: 399405.

4. Roberts JD, Polander DM, Lanf P, Zapol WM. Inhaled nitric oxide in persistent pulmonary hypertension of the newborn. Lancet 1992; 340: 818-819.

5. Kinsella JP, Neish SR, Shaffer E, Abman SH. Lowdose inhalational nitric oxide in persistent pulmonary hypertension of the newborn. Lancet 1992; 340: 819-820. 
6. Dupuy PM, Shore SA, Drazen JM, Frostell C, Hill WA, Zapol WM. Bronchodilator action of inhaled nitric oxide in guinea-pigs. J Clin Invest 1992; 90: 421-428.

7. Högman M, Frostell C, Arnberg H, Hedenstierna G. Inhalation of nitric oxide modulates methacholine-induced bronchoconstriction in the rabbit. Eur Respir J 1993; 6: 177-180.

8. Högman M, Hedenström $\mathrm{H}$, Frostell $\mathrm{C}$, Arnberg H, Hedenstierna G. Is nitric oxide inhalation beneficial to the asthmatic patient? Intensive Care Med 1992; 18: S169.

9. Flecknell PA. In: Laboratory Animal Anesthesia. Academic Press, New York, 1987; pp. 128-129.

10. West J. Alveolar-arterial differences. In: Ventilation: Blood Flow and Gas Exchange. 3rd edn. Oxford, Blackwell, 1977; pp. 102-103.

11. Quan SF, Witten ML, Stevenson JL, Roseberry HR, Lemen RJ. Variability of pulmonary responsiveness to aerosolized histamine in normal rabbits. Respiration 1986; 50: 108-116.

12. Bates JHT, Milic-Emili J. The flow interruption technique for measuring respiratory resistance. $J$ Crit Care 1991; 6: 227-238.

13. Hughes R, May AJ, Widdicombe JG. Stress relaxation in rabbits' lung. J Physiol (Lond) 1959; 146: 85-97.

14. Kochi T, Okubo S, Zin WA, Milic-Emili J. Flow and volume dependence of pulmonary mechanics in anesthetized cats. J Appl Physiol 1988; 64: 441-450.

15. Masaki Y, Munakata M, Ukita H, Homma Y, Kawakami
Y. Nitric oxide (NO) can relax canine airway smooth muscle. Am Rev Respir Dis 1989; 139: A350.

16. Kacmarek RM, Cockrill BA, Ripple RE, Donohoe M, Zapol WM, Johnson D. Nitric oxide as a bronchodilator in methacholine induced bronchospasm in mild asthmatics. Am Rev Respir Dis 1993; 147: A835.

17. Alving K, Fornhem C, Weitzberg E, Lundberg JM. Nitric oxide mediates cigarette smoke-induced vasodilatory responses in the lung. Acta Physiol Scand 1992; 146: 407-408.

18. Watanabe AM. Achetylcholine receptor stimulants. In: Katzung BG, ed. Basic and Clinical Pharmacology. Lange Medical Publications, 1984; pp. 64-68.

19. O'Byrne PM. The airway epithelium and asthma. In: Farmer SG, Hay DWP, eds. The Airway Epithelium: Physiology, Pathophysiology, and Pharmacology. New York, Dekker, 1991; pp. 171-186.

20. Bylin G, Hedenstierna G, Lindvall T, Sundin B. Ambient nitrogen dioxide concentrations increase bronchial responsiveness in subjects with mild asthma. Eur Respir $J$ 1988; 1: 606-612.

21. Orehek J, Massari JP, Gayrard P, Grimaud C, Charpin J. Effects of short-term, low-level nitrogen dioxide exposure on bronchial sensitivity of asthmatic patients. J Clin Invest 1976; 57: 301-307.

22. Rasmussen TR, Kjaergaard SK, Tarp U, Pedersen OF. Delayed effects of $\mathrm{NO}_{2}$ exposure on alveolar permeability and glutathione peroxidase in healthy humans. $\mathrm{Am}$ Rev Respir Dis 1992; 146: 654-659. 